\title{
EDITORIAL / REDAKSIONEEL
}

A special planning session during the CASA conference held at the University of South Africa in January 2001 specifically paid attention to the question of the future of Classics in South Africa. Apart from inter-departmental ventures such as the sharing of resources and expertise, it was agreed that efforts should be made to promote an awareness of Classics among the general public.

One of the proposals that met with unanimous approval was that Akroterion should cater for a broader reading public by publishing articles that have a general appeal without sacrificing their academic value. This volume of Akroterion is the first step in that direction, including five illustrated contributions ranging from topics as far apart as Egyptian pyramids and the Hartbeespoort Dam.

In hierdie volume is 'n huldeblyk aan prof C P T Naudé wat in Augustus 2001 oorlede is. Pas voordat die manuskrip vir die drukker gefinaliseer is, is ook berig ontvang van die afsterwe van mnr L J D la Grange, afgetrede senior lektor van die Departement Latyn aan die Universiteit van Pretoria, op 28 Julie 2002. Seneca se woorde (Ep. 54.7) vat die wese van oom Louis, soos sy studente hom genoem het, pragtig saam:

Illum tu lauda et imitare quem non piget mori, cum iuvet vivere.

"Jy moet daardie man bewonder en naboots wat nie omgee om te sterf alhoewel hy vreugde put uit die lewe nie."

\section{J C ZIETSMAN}

Acting editor / Waarnemende redakteur 